
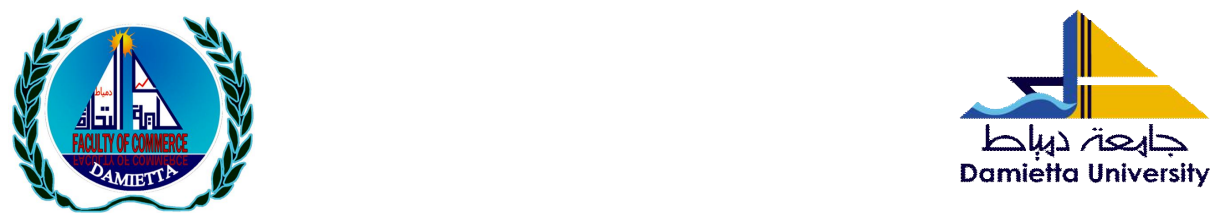

\title{
Examining the mediating Effect of Strategic Agility in the Relationship between Organizational Learning Mechanisms and Organizational Excellence: The Case of Kafrelsheikh University's Employees
}

\author{
Prepared by \\ Dr. Shahesta Elsaid Lebda \\ Lecturer - Business Administration Department \\ Faculty of Commerce - Kafrelsheikh University \\ shahylebda@gmail.com
}

Scientific Journal for Financial and Commercial Studies and Researches (SIFCSR)

Faculty of Commerce - Damietta University

Vol.3, No.1, Part 1., January 2022

APA Citation:

Lebda, S. E. (2022). Examining the mediating Effect of Strategic Agility in the Relationship between Organizational Learning Mechanisms and Organizational Excellence: The Case of Kafrelsheikh University's Employees, Scientific Journal for Financial and Commercial Studies and Research, Faculty of Commerce, Damietta University, 3(1)1.pp.285-314.

Website: https://cfdj.journals.ekb.eg/ 
Scientific Journal for Financial and Commercial Studies and Researches

(SJFCSR) Faculty of Commerce - Damietta University

\title{
Examining the mediating Effect of Strategic Agility in the Relationship between Organizational Learning Mechanisms and Organizational Excellence: The Case of Kafrelsheikh University's Employees
}

\author{
Dr. Shahesta Elsaid Lebda
}

\begin{abstract}
This study aims to investigate and deliberates the relationship between Organizational Learning Mechanisms, strategic agility, and organizational excellence in Employees of Kafrelsheikh University. Moreover, it examined the effect of strategic agility as a moderator of this relationship between Organizational Learning Mechanisms and organizational excellence. A total of 325 questionnaires were collected from respondents who were chosen from a stratified random sampling. The findings indicate that Organizational Learning Mechanisms and its dimensions, Knowledge recognition mechanisms, Knowledge assimilation mechanisms, and Knowledge exploitation mechanisms have a significant impact on strategic agility as well as organizational excellence. Moreover, the results indicate that strategic agility partial mediates the relationship between Organizational Learning Mechanisms and organizational excellence. The findings of this study can have significant implications for Employees of Kafrelsheikh University. The study observes that there is a critical shortage of Strategic Agility, Organizational Learning Mechanisms and that a greater understanding of the factors that influence the Organizational Excellence is needed, Therefore, Organizational Learning Mechanisms can lead to Organizational Excellence and Strategic Agility.
\end{abstract}

Keywords: agility, excellence, Organizational Learning Mechanisms, performance. 


\section{Dr. Shahesta Elsaid Lebda}

\section{Introduction:}

Undoubtedly, in today live at a time of technological change that is unprecedented in its pace, scope and depth of impact, technical and cognitive progress is a key driver to push organizations all over the world to walk at a fast pace toward becoming a learning organization. The newest administrative pattern recently spread to replace traditional forms in organizations management, where it is working on rearranging their positions to benefit from previous experiences and participation of workers in the stock of knowledge, and strengthen it to serve the technical side and realize the aspirations and hopes of the communities and contribute to the survival of these organizations and their continuation.

As the pace of change in higher education continues to accelerate, the mission of universities has changed over years, and universities across the globe presently are increasingly pressed to change demographics, globalization, decrease in state funding, increase of online technology, heterogeneous student population, etc. The University today face demanding challenges, such as expectations to be agile, competitive, efficient and adept to using employee knowledge. There are several required virtues in order to have a conductive workplace, for example, organizational learning and agility.

University institutions are strongly seeking excellence. This requires university management to provide a supportive environment for organizational learning, and extract knowledge from the minds of its members, through the formation of a common vision among employees to contribute to the creation of the strategic changes that is required for excellence (Attalah \& Naser 2014).

Organizational learning (OL) is a conceptually rich construct that can inform understandings of a wide range of organizational phenomena. The field of university, however, lacks a sufficient body of empirical research on organizational learning in colleges and universities. In reality, higher education institutions have long been regarded as centers of knowledge creation and application for the larger society, but not only as learning organizations developing and transferring knowledge for the 
Scientific Journal for Financial and Commercial Studies and Researches

(SJFCSR) Faculty of Commerce - Damietta University

improvement of their own basic processes. but the learning would be the central work of higher education institutions (Dill,1990).

Both organizational learning capability and strategic agility are prerequisites for university survival and success. The Organizational learning (OL)have a direct effect on organizational excellence and it have also indirect effect on organizational excellence by improving other organizational outcomes such as organizational excellence. This paper suggests that strategic agility is one of those variables and that it mediates the relationship between organizational learning and organizational excellence and that the adoption of a organizational learning enhances organizational excellence through its positive effect on strategic agility excellence in Employees of Kafrelsheikh University.

Therefore, this piece of study endeavors to figure out, first, the development of the conceptual model and the hypotheses of the study are presented. Next, the methodology of the study is discussed followed by the analysis and results. More specifically, the conceptual model is tested using path analysis, with the AMOS 19 structural equation modeling package, and data collected from a mail survey of 600 Employees of Kafrelsheikh University. Finally, the conclusions and their implications are discussed.

As a result, this study will try to define what dimensions of organizational learning mechanisms affect organizational excellence. Accordingly, try to answer the main question "what is the impact of organizational learning mechanisms on organizational excellence of Employees of Kafrelsheikh University in the presence of strategic agility". This study contributes to the literature in different ways.

\section{Literature review:}

\section{Organizational learning mechanism (OLM):}

The concept of learning organization was initiated in 1900, when Teylor discovered the positive effect of the knowledge transfer on the performance and productivity, while Cyert and March were the first scholars who put learning and organization together and created organizational learning phrase in the organization literature (Nemeth, 1997). organizational learning is a dynamic social system defined as "a 


\section{Dr. Shahesta Elsaid Lebda}

system of actions, actors, symbols, and processes that enables an organization to transform information into valued knowledge, which, in turn, increases its long-run adaptive capacity" (Schwandt, 1995: 370).

Organizational Learning (OL) is a vital component in any effort to improve organizational performance and to Organizational excellence. Organizational learning as the capability of an organization to process knowledge, in other words, to create, acquire, transfer, and integrate knowledge, and to modify its behavior to reflect the new cognitive situation, with a view to improving its performance (Jerez-Gomez et al. ,2005).

OL can be viewed as the ability of organization as a whole for detecting errors and correcting as well as changing the existing organizational knowledge and values so as the new problem solving skills and capacity could be introduced and applied to work (Hoffman et al. 2005).

OL was defined as the process of improving actions through better knowledge and understanding (Fiol \&Lyles, 1985), organizational learning is the way in which the organizations learn. It is characterized as an essential component in organizations that operate in turbulent environments, in which knowledge acts as a key resource (JiménezJiménez, J.G., Cegarra-Navarro, 2007), Organizations that emphasize the learning in this type of environment are able to achieving organizational excellence.

Organizational learning process understood as the organization tangible and intangible resources, as skills that act as a way of promoting competitive advantage, and that allows the organizational learning process (Alegre, Chiva, 2008).

Organizational Learning is in describing as "accumulated knowledge" (Dixon,1994). Organizational learning is seen as a system that able to transform information into valuable knowledge for a long term sustainability of an organization (Johnson \& Bailey, 2010). Organizational Learning, or the process through which organizations change or modify their models, processes or knowledge, maintaining or improving their performance (Chiva ,Ghauri. \& Alegre ,2014). 
Scientific Journal for Financial and Commercial Studies and Researches

(SJFCSR) Faculty of Commerce - Damietta University

Organizational learning is positively related to the quality of the team cooperation (Sessa et al., 2011).

OL is the process by which the organization increases the Knowledge created by individuals in an organized way and transforms this knowledge into part of the organization's knowledge system (GarcíaMorales et al., 2012). Successful organizational learning depends on the acquisition and assimilation of diverse new bases of knowledge for subsequent actions (Ghoshal, 1987).

Organizations use mechanisms that help their members to interpret information, to exchange views, attitudes and information, and to transfer tacit knowledge that individuals carry with them, in order to create new organizational knowledge (Lee et al., 1992; Nonaka \& Takeuchi, 1995).

Organizational members must invest effort in developing institutionalized organizational learning mechanisms (OLM) aiming to revise and develop their knowledge by facilitating information gathering and elaboration, or by intensifying processes of information dissemination, storage, and retrieval (Lipshitz et al., 2002).

The Dimensions of organizational learning mechanism:

According to (Berghman,2012) there are three dimensions to organizational learning mechanism: Knowledge recognition, Knowledge assimilation and Knowledge exploitation

1. Knowledge recognition: Knowledge creation and innovation must be understood as a process by which the knowledge individuals possess is extended and internalized as part of the organizational knowledge (Zahra, S. A., \& George, G. ,2002).

acquisition External knowledge is a very important resource for learning new techniques, solving problems, creating core competencies, and building new opportunities for organizations (Gebauer, H. ,2011). knowledge recognition is the ability of university to identify, acquire, integrate, transfer, and use from the knowledge gained from external resources.

2. Knowledge assimilation: The information and knowledge gathered from the environment must be converted into a transferable form and distributed internally through the internalization process that requires 


\section{Dr. Shahesta Elsaid Lebda}

dissemination and assimilation. dissemination, involves the communication of the generated knowledge to all relevant departments and individuals (Liao, Welsch, \& Stoica, 2003).

3. Knowledge exploitation: using the assimilated knowledge to create new knowledge and outputs

\section{Strategic Agility (SA):}

Recently, Organizational learning has been in the focus of attention in areas such as

organizational behavior and strategic management. An organization's ability to learn is a Key strategic capability to compete (Santos-Vijande et al., 2012). Strategic Agility (SA) is defined by (Arokodare, M. A. \& Asikhia, O. U. ,2020) as a concept consisting of two components: responsiveness and knowledge management.(Mellahi, et al.2020) define strategic agility as "timely decision-making to execute business strategies in advance of or in reaction to ongoing environmental trends" Strategic agility is the ability of leaders to respond in real-time to change and uncertainty, consciously using tools and practices to effectively apply strategic thinking for institutional learning and creating innovative solutions that establish a sustainable advantage for their education organizations. Strategic agility represents a way of challenging a university to boost its capability, Research on strategic agility suggests that organisations may dynamically manage resources to adapt to a dynamic environment by building resource flexibility and coordination flexibility (Zhou and Wu, 2012).

\section{The Dimensions of Strategic Agility:}

According to Doz \& Kosonen, (2008) there are three dimensions to strategic agility: strategic sensitivity, collective commitment and resource fluidity

1. Strategic Sensitivity: sensitivity is particularly pertinent to leadership at universities as they observe and monitor innovations unfolding from a distance, explore new opportunities and markets through digital transformation and different business models, the ability to be open to a lot of information, intelligence and innovations 
Scientific Journal for Financial and Commercial Studies and Researches

(SJFCSR) Faculty of Commerce - Damietta University

offered by multiple relationships with organizations and other people (Santala, 2009).

2. Collective Commitment: The ability of the top team and the organizational leadership to make and implement bold joint strategic decisions fast, and to carry through implementation with high energy

3. Resource Fluidity: Resource fluidity involves the internal capability to reconfigure business systems and redeploy resources speedily, supported businesses processes for operations and resource allocation, people management approaches, mechanisms and incentives for collaboration that make business models and activity system transformation quicker and easier (Doze \& Kosonen, 2008).

\section{Organizational Excellence (OE):}

Organizational Excellence (OE): is the ability of the organization to provide opportunities, and the appropriate environment that seeks to stimulate, correct and effectively address problems (Grote, 2002).

Organization Excellence was defined as a crucial investment opportunity by organizations that preceded effective strategic planning and commitment to realize a common vision dominated by clarity of purpose and adequacy of resources and ensure the performance (Raftery, D.,2006).

There are several determinants to achieve OE, such as the presence of visionary leadership, focusing on the future through strategic planning, activating the role of knowledge and adaption of organizational learning (Grant, 2000).

\section{The Dimensions of Strategic Agility:}

Organizational Excellence is a set of dimensions; the most important dimensions of excellence in the universities are as follows:

1. Leadership excellence to address the many obstacles facing workers in university, the need to strong leadership at all levels, service and administrative areas. recently contemporary management requires superior capabilities of the leaders; to be able to keep up with developments and changes, so the leadership must play a major role in creating vision, communicating policy, and deploying strategy if we need leadership excellence. 


\section{Dr. Shahesta Elsaid Lebda}

2. Services excellence : argue that corporate success will not depend exclusively on productivity and growth (both of which are important factors) but also on the careful application of reactive and proactive managerial processes that ensure that employees are well trained and performing to their best abilities (Swart and Duncan ,2005). views that service excellence is about looking after the wellbeing of staff members, training them and ensuring that they are contented and committed to look after clients to the best of their abilities (Reed and Vakola's ,2006) . The lack of qualified/specialized staff and insufficient resources are great concerns in university, as these often result in heavy workloads and staff being forced to deliver services for which they are not skilled or experienced. Moreover, universities are struggling to recruit trained and appropriately qualified or experienced staff.

3. knowledge excellence: Anticipatory leaders and managers exhibit cognitive excellence through a constant flow of insights and foresights that resolve uncertainties and problems. These professionals become a critical resource to highly effective cognitive operations. Organizations need to instill these anticipatory capabilities in their professionals to achieve greater business performance.

In the following paragraph, we explain each category of organizational learning mechanisms in detail and hypothesize their relationship with strategic agility and organizational excellence.

\section{Conceptual model of the study:}

Following diagram (figure1) proposes relationship between variables. In the current study, researchers attempt to examine relationship between Organizational Learning Mechanisms (OLM), organizational excellence (OE), and strategic agility (SA). Finally, in achieving the final research model, a structural equation model is used to investigate the effect of strategic agility as a mediator in the relationship between Organizational Learning Mechanisms and organizational excellence. 
Scientific Journal for Financial and Commercial Studies and Researches

(SJFCSR) Faculty of Commerce - Damietta University

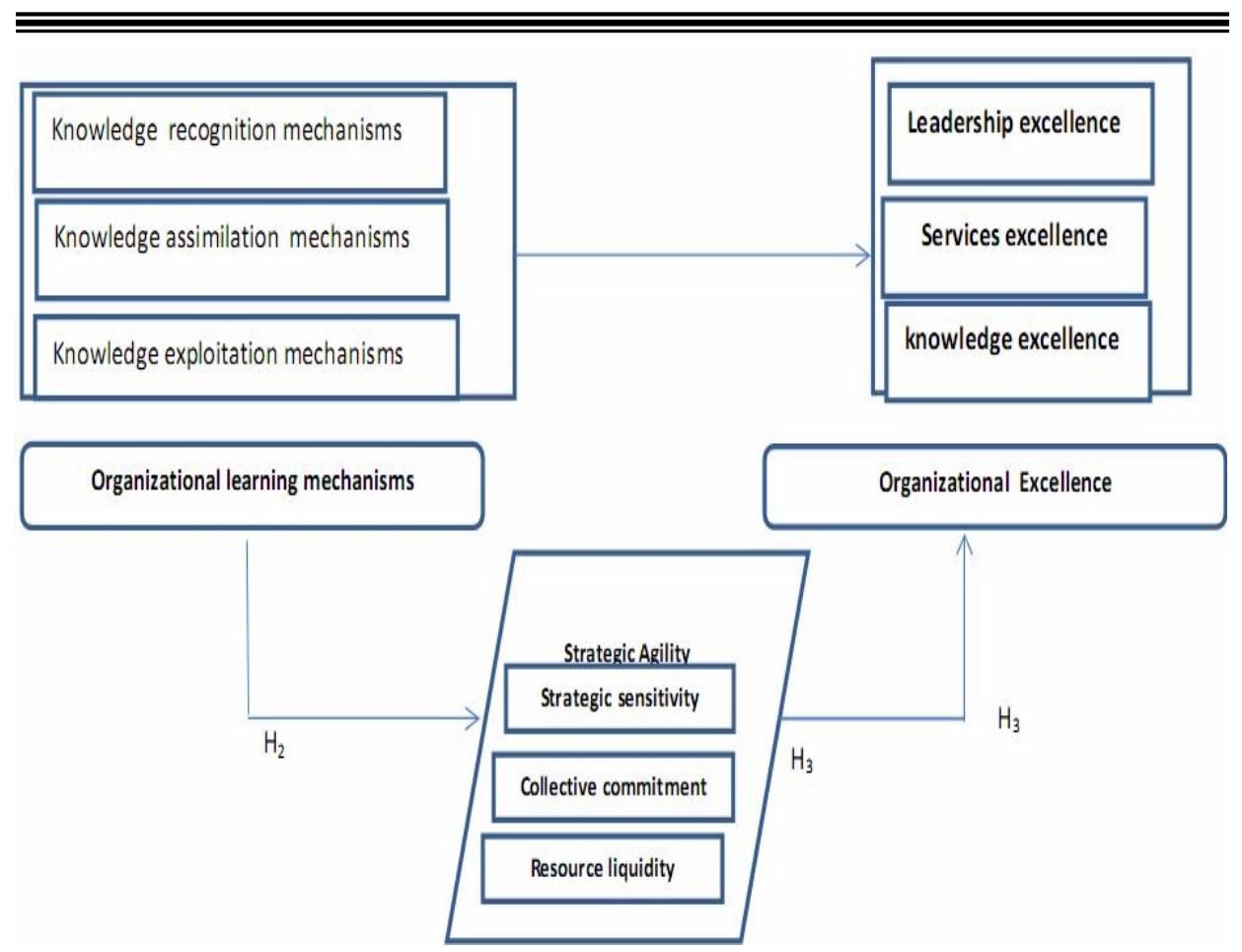

Figure 1: Research Conceptual Model

Based on the above model, researchers have developed the following hypothesis:

H01: There is a significant statistical effect of Organizational Learning Mechanisms on Organizational Excellence.

$\mathrm{H}_{0} 2$ : There is a significant statistical effect of Organizational Learning Mechanisms and Organizational Agility.

$\mathrm{H}_{0}$ 3: There is a significant statistical effect of Strategic Agility on Organizational Excellence.

$\mathrm{H}_{0}$ 4: Strategic Agility is mediating the effect in the relationship between Organizational Learning Mechanisms and Organizational Excellence. 


\section{Dr. Shahesta Elsaid Lebda}

\section{Methodology}

\subsection{Constructs operationalization}

The current study adopts the demonstrative analytical approach, aiming to examine the mediating effect of Strategic Agility in the relationship between Intellectual Capital and Organizational Excellence in Jordanian Service Sector. The current study adopts the demonstrative analytical approach, aiming to examine the mediating effect of Strategic Agility in the relationship between Intellectual Capital and Organizational Excellence in Jordanian Service Sector.

The current study adopts the demonstrative analytical approach, aiming to examine the mediating effect of Strategic Agility in the relationship between Intellectual Capital and Organizational Excellence in Jordanian Service Sector.

The current study adopts the demonstrative analytical approach, aiming to examine the mediating effect of Strategic Agility in the relationship between Intellectual Capital and Organizational Excellence in Jordanian Service Sector This study is descriptive, quantitative in nature, based on both primary and secondary data. It starts with literature review that explores the variables of the study (Organizational Learning Mechanisms; strategic agility; and organizational excellence).

Our literature review enabled us to design a conceptual framework. An Applied study has been designed to test the model; therefore, primary data collection was based on a questionnaire( which was randomly distributed to Employees of Kafrelsheikh University. based on equal stratified random sampling. Items used in the questionnaire were based on a Likert scale which was administered $(7=$ strongly agree up to $1=$ strongly disagree), because the online survey is achieving faster results and proving to be effective in running time, 300 questionnaires were successfully distributed and collected online on a random stratified sample of employees of data analysis. table one show demographic variables which analyzed using frequency counts and simple percentage. 
Scientific Journal for Financial and Commercial Studies and Researches (SJFCSR) Faculty of Commerce - Damietta University

Table (1) demographic variables

\begin{tabular}{|c|c|c|c|c|}
\hline No. & Variables & Categories f & frequency & percent \\
\hline \multirow{2}{*}{1} & \multirow{2}{*}{ Gander } & Male & 170 & 55.7 \\
& & female & 135 & 44.3 \\
\hline \multirow{3}{*}{2} & \multirow{3}{*}{ Age } & 30 years or less & 40 & 13.1 \\
& & $30-$ less than 39 years & 101 & 33.1 \\
& & $40-$ less than 45 years & 60 & 19.7 \\
& & 45 year and above & 104 & 34.1 \\
3 & \multirow{3}{*}{3} & Less than 5 years & 19 & 6.2 \\
& Work & $5-$ less than 10 years & 79 & 25.9 \\
& & $10-$ less than 15 years & 86 & 28.2 \\
& & 15 year and above & 121 & 39.7 \\
\hline \multirow{3}{*}{4} & \multirow{3}{*}{ Education } & Intermediate & 39 & 12.8 \\
& level & Above average & 25 & 8.2 \\
& & University & 140 & 45.9 \\
& & postgraduate & 101 & 33.1 \\
\hline
\end{tabular}

\subsection{Survey administration and sample}

This study was conducted in Egypt. The location of the study was Kafrelsheikh University because Egypt universities face several challenges and environmental difficulties, which (change) change is an inherent feature. If universities are adapting to these changes successfully, they must look for effective and fast strategies to be successful. Strategic agility is one of those strategies that ensure adaptation and success, and as a relatively new area of study. Which stimulated researcher to carry out the research as an attempt to spread the culture of strategic agility in the higher education sector in general and the University of Kafrelsheikh in particular, which today is in dire need to adopt such a concept and include in the philosophy and practices.

The sample size was to be determined according to the Thompson (326) sample size equation, which is widely accepted by social science 


\section{Dr. Shahesta Elsaid Lebda}

researchers, since it takes into account the degree of required confidence, the sample error, ratio of population characteristics

available in the sample (50\% in social sciences) and population size. According to Thompson, S (326), the sample size can be determined according to the following equation (Thompson, (2012):

$$
n=\frac{N \times p(1-p)}{\left.\left.\llbracket N-1 \times\left(d^{2} \div z^{2}\right)\right]+p(1-p)\right]}
$$

\section{Where:}

$\mathrm{N}$ : sample size

$\mathrm{N}$ : population size

$\mathrm{Z}$ : confidence Level at $95 \%$

$\mathrm{d}$ : Error proportion

p: probability $(50 \%)$

\subsection{Data Analysis and Results}

A Statistical Package for Social Sciences (SPSS version 20) was used to test the study hypothesis through using multiple regression analysis to examine the impact of Organizational Learning Mechanisms on Organizational Excellence, Organizational Learning Mechanisms on Strategic Agility, and Strategic Agility on Organizational Excellence. To examine the mediating effect of Strategic Agility in the Relationship between Organizational Learning Mechanisms and Organizational Excellence a hierarchical regression analysis was also used.

\subsection{Factor Analysis and reliability Coefficients:}

In analyzing the data, an exploratory factor analysis was used. Summary of the construct of factor analysis is shown in Table 2. In the reliability scale, Cronbach's Alpha was used to examine the consistency of the measurement variables (Sekaran \& Bougie, 2013). According to (Hsu, Liu, and Lee ,2010) who suggest that for items to achieve internal consistency, it should have a value of more than 0.70 with 0.5 being the least acceptable value while (Hair, Balck, Babin, Anderson, and Tatham, 2006) suggested that the coefficient should be at the minimum acceptable level 0.74. Controversially, (Sekaran and Bougie ,2016) indicated that the 
Scientific Journal for Financial and Commercial Studies and Researches (SJFCSR) Faculty of Commerce - Damietta University

closer the Cronbach's alpha to the value of 1, the higher the internal consistency reliability. Table 1 shows all the Cronbach's alpha values of the studied variables to be more than 0.70 .

As shown, Organizational Learning Mechanisms have scored Cronbach's Alpha value of 0.934 (Knowledge recognition), 0.922 (Knowledge assimilation)،and 0.923( Knowledge exploitation), respectively. Organizational Excellence dimensions have a Cronbach's alpha value of 0.890 (Leadership excellence), 0.882 (Services excellence and 0.750 (knowledge excellence), while the Strategic Agility dimensions score Cronbach's Alpha value of 0.909 (Strategic Sensitivity),0.890 (Collective commitment), and 0.844 (Resource Fluidity).

Table 2. factor analysis and reliability Results for Study Variables

\begin{tabular}{|c|c|c|c|c|}
\hline Variables & Categories & $\begin{array}{l}\text { No. of } \\
\text { Items }\end{array}$ & $\begin{array}{l}\text { Factor } \\
\text { loading }\end{array}$ & $\begin{array}{c}\text { Cronbach's } \\
\text { Alpha } \\
\end{array}$ \\
\hline $\begin{array}{l}\text { Organizational } \\
\text { Learning } \\
\text { recognition }\end{array}$ & Knowledge & 5 & 0.946 & 0.934 \\
\hline $\begin{array}{l}\text { Mechanisms } \\
\text { assimilation }\end{array}$ & Knowledge & 3 & 0.950 & 0.922 \\
\hline exploitation & Knowledge & 5 & 0.904 & 0.923 \\
\hline Organizational & $\begin{array}{l}\text { Leadership } \\
\text { excellence }\end{array}$ & 4 & 0.944 & 0.890 \\
\hline \multirow[t]{2}{*}{ Excellence } & $\begin{array}{c}\text { Services } \\
\text { excellence }\end{array}$ & 3 & 0941 & 0.882 \\
\hline & $\begin{array}{l}\text { knowledge } \\
\text { excellence }\end{array}$ & 3 & 0.870 & 0.750 \\
\hline Strategic & $\begin{array}{c}\text { Strategic } \\
\text { sensitivity }\end{array}$ & 6 & 0.925 & 0.909 \\
\hline \multirow[t]{2}{*}{ Agility } & $\begin{array}{c}\text { Collective } \\
\text { commitment }\end{array}$ & 4 & 0.937 & 0.890 \\
\hline & $\begin{array}{l}\text { Resource } \\
\text { Liquidity }\end{array}$ & 7 & 0805 & 0.844 \\
\hline
\end{tabular}




\section{Dr. Shahesta Elsaid Lebda}

\subsection{Descriptive and correlation analysis}

Table 3 shows that Organizational Learning Mechanisms variable has mean scores over than 3.00. Specifically, the three dimensions of Organizational Learning Mechanisms have a mean value of 3.829 (Knowledge recognition), 3.650 (Knowledge assimilation), and 3.744 (Knowledge exploitation). Respondents' attitudes toward applicability of Organizational Learning Mechanisms in Employees of Kafrelsheikh University were obviously identified. However, attitudes toward Strategic Agility dimensions have a mean value of 3.720 (Strategic Sensitivity), 3.577 (Collective commitment، and 3.815 (Resource Fluidity. Moreover, the respondents tend to be more familiar with organizational excellence atmosphere in term of its dimensions, the mean value of 3.717 (Leadership excellence), 3.655 (Services excellence), 3.625 (knowledge excellence) .

Pearson correlation coefficients computed for the relationships among study variables were found positive and significant. All the dimensions of Organizational Learning Mechanisms were found to be strongly and positively correlated with Organizational Excellence and Strategic Agility.

Therefore, the Pearson correlation matrix indicates that all variables are significant and positively correlated. The correlation coefficient values were in the range of $0.698(p>0.01)$ to $0.879(p<0.01)$. 
Scientific Journal for Financial and Commercial Studies and Researches (SJFCSR) Faculty of Commerce - Damietta University

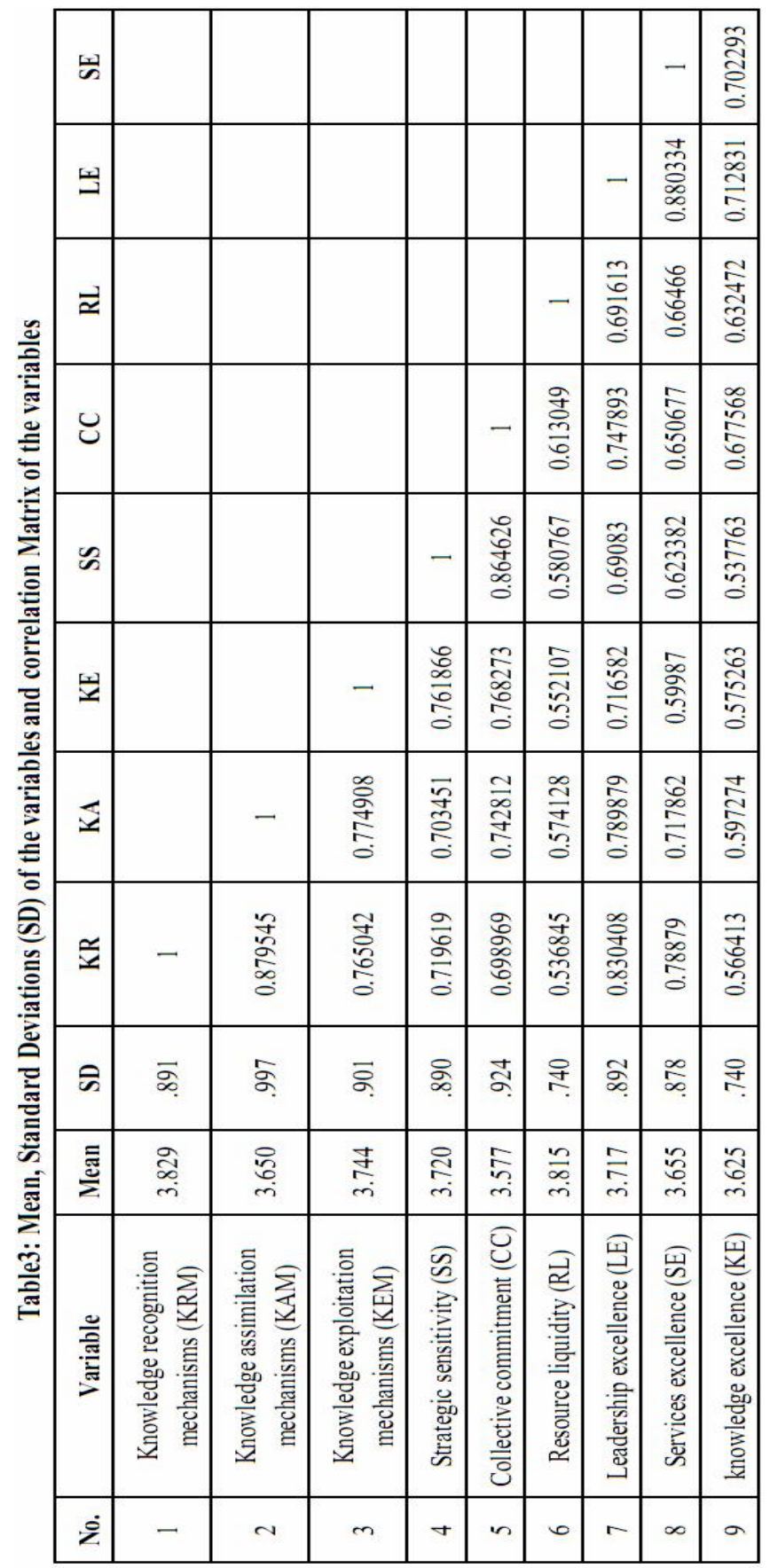




\section{Dr. Shahesta Elsaid Lebda}

Table 4, 5, and 6 show the results of the regression analysis of the study hypothesis 1, 2, and 3. Table 4 demonstrates that Organizational Learning Mechanisms explains $65.2 \%$ variances in Organization Excellence $(\mathrm{OE})(\mathrm{R} 2=0.652, \mathrm{p}<0.01)$. Additionally, all dimensions of Organizational Learning Mechanisms have a positive relationship with Organizational Excellence. Knowledge recognition has a standard coefficient beta ( $\beta$ Value of 0.277 while Knowledge assimilation has a standard coefficient beta $(\beta)$ value of 0.291 Knowledge exploitation has a standard coefficient beta $(\beta)$ value of 0.979 . All these Dimensions had a significant $p$-value, which was, less than 0.01 . Knowledge exploitation dimension has the strongest effect on Organizational Excellence as compared to other Organizational Learning Mechanisms dimensions. Because all three dimensions of Organizational Learning Mechanisms were found to have a direct and positive effect on Organizational Excellence at a significant level, $\mathrm{H} 1 \mathrm{a}, \mathrm{H} 1 \mathrm{~b}$, and $\mathrm{H} 1 \mathrm{c}$ are corroborated strongly and, hence, the first hypothesis (H1) stands confirmed.

Table 5 shows the regression analysis of the second hypothesis. The results depict that Organizational Learning Mechanisms explains $68.2 \%$ variances in Strategic Agility $(\mathrm{R} 2=0.682 ، \mathrm{p}<0.01)$. All Organizational Learning Mechanisms dimensions are significantly and positively correlated with the Strategic agility: Knowledge recognition $(\beta=0.277, \mathrm{p}<0.01)$, Knowledge assimilation $(\beta=0.952, \mathrm{p}<0.01)$, and Knowledge exploitation $(\beta=0.346, p<0.01)$. Knowledge exploitation has the strongest effect on strategic agility as compared to Knowledge recognition and Knowledge assimilation. The overall results lend strong support to $\mathrm{H} 2 \mathrm{a}, \mathrm{H} 2 \mathrm{~b}$ and $\mathrm{H} 2 \mathrm{c}$ and hence the second hypothesis $(\mathrm{H} 2)$ stands verified.

Finally, Table 6 demonstrates that $68.4 \%$ variances in Organizational Excellence explained by the Strategic Agility $(\mathrm{R} 2=0.684$, $\mathrm{p}<0.01)$. As shown in the table, results indicate that Strategic Sensitivity ( $\beta=02.435, p<0.01)$ while Collective commitment $(\beta=0.535, p<0.01)$, and Resource liquidity $(\beta=0.193, p<0.01)$. the third hypothesis $(\mathrm{H} 3)$ stands verified. 
Scientific Journal for Financial and Commercial Studies and Researches (SJFCSR) Faculty of Commerce - Damietta University

Table 4. Regression analysis of organizational learning mechanisms on organizational excellence

\begin{tabular}{|c|c|}
\hline Variable & Standard Coefficient \\
\hline Organizational Learning Mechanisms Dimensions & \\
\hline Knowledge recognition mechanisms & 0.277 \\
\hline Knowledge assimilation mechanisms & 0.291 \\
\hline Knowledge exploitation mechanisms & 0.979 \\
\hline R2 & 0.652 \\
\hline Adjusted R2 & 0.648 \\
\hline Sig. F & 187.72 \\
\hline
\end{tabular}

**Regression is significant at the 0.01 level $(p<0.01)$.

Table 5. Regression Analysis of Organizational Learning Mechanisms on Strategic Agility

\begin{tabular}{|c|}
\hline Variable Standard Coefficient \\
\hline Organizational Learning Mechanisms Dimensions \\
\hline Knowledge recognition mechanisms 0.277 \\
\hline Knowledge assimilation mechanisms 0.952 \\
\hline Knowledge exploitation mechanisms 0.346 \\
\hline R2 0.682 \\
\hline Adjusted R2 0.678 \\
\hline Sig. F 214.84 \\
\hline
\end{tabular}

**Regression is significant at the 0.01 level $(p<0.01)$. 
Dr. Shahesta Elsaid Lebda

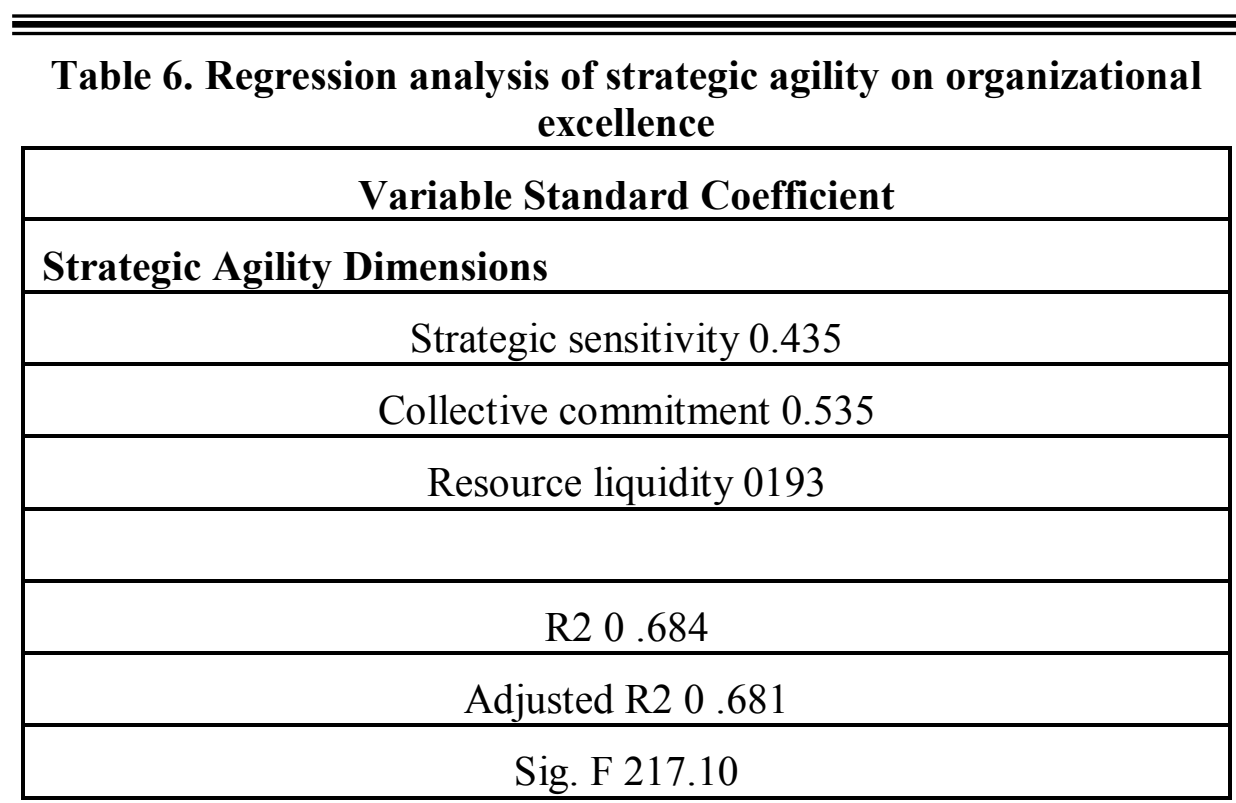

**Regression is significant at the 0.01 level $(\mathbf{p}<0.01)$.

Tests for mediation were conducted. If there are significant relationships from (1) through (3), a hierarchical regression analysis is performed on all Organizational Learning Mechanisms dimensions (independent variable) with Strategic agility (mediator) and Organizational Excellence (dependent variable) to investigate the type of the mediation whether is full or partial mediation (Yasin, Ramayah, Mohamad\& ، Wah, 2009).

Following Kenney \& Baron (1986), who took steps in this regard what he presented in the context, it is observed that the mediating effect will not be achieved unless there is a substantial effect of the independent variable on the median variable itself. 
Scientific Journal for Financial and Commercial Studies and Researches (SJFCSR) Faculty of Commerce - Damietta University

Table 7. Regression Analysis Results for the Mediation of Strategic Agility

\begin{tabular}{|c|c|c|c|}
\hline Variable & $\begin{array}{c}\text { Std. } \\
\text { coefficients } \\
\text { without } \\
\text { Mediator } \\
\text { (Model 1) }\end{array}$ & $\begin{array}{l}\text { Std. coefficients } \\
\text { with } \\
\text { Mediator } \\
\text { (Model 2) }\end{array}$ & Results \\
\hline \multicolumn{4}{|l|}{$\begin{array}{c}\text { Independent } \\
\text { Variables: } \\
\text { Organizational } \\
\end{array}$} \\
\hline \multicolumn{4}{|l|}{ Learning Mechanisms } \\
\hline $\begin{array}{c}\text { Knowledge recognition } \\
\text { mechanisms }\end{array}$ & 0.277 & 0.275 & $\begin{array}{c}\text { partial } \\
\text { mediation }\end{array}$ \\
\hline $\begin{array}{c}\text { Knowledge assimilation } \\
\text { mechanisms }\end{array}$ & 0.291 & .579 & $\begin{array}{c}\text { partial } \\
\text { mediation }\end{array}$ \\
\hline $\begin{array}{c}\text { Knowledge exploitation } \\
\text { mechanisms }\end{array}$ & 0.979 & .490 & $\begin{array}{c}\text { partial } \\
\text { mediation }\end{array}$ \\
\hline $\begin{array}{c}\text { Mediator: Strategic } \\
\text { Agility }\end{array}$ & & 0.712 & \\
\hline $\begin{array}{l}\text { All independent } \\
\text { variable }\end{array}$ & 0.925 & 0.523 & \\
\hline $\mathrm{R}^{2}$ & 0.640 & 0.699 & \\
\hline Adjusted $\mathrm{R}^{2}$ & 0.639 & 0.697 & \\
\hline $\mathrm{R}^{2}$ change & 0.640 & 0.699 & \\
\hline F-change & 537.9 & .350 .771 & \\
\hline
\end{tabular}

$* *$ Regression is significant at the 0.01 level $(\mathrm{p}<0.01)$. 


\section{Dr. Shahesta Elsaid Lebda}

\section{Discussion}

Organizational Learning Mechanisms has a significantly positive relationship with the Organizational Excellence for Employees of Kafrelsheikh University. Among the three dimensions of OLM, Knowledge assimilation mechanisms has the strongest effect on OE, followed by Knowledge recognition mechanisms as the second strongest effect on Organizational excellence, then the Knowledge exploitation mechanisms occupies the lowest effect.

In other words, Employees in Kafrelsheikh University consider Knowledge assimilation mechanisms the producer of the University and as a source of the prerequisites for them. Whereas, it is important within the university to allow new external information and knowledge to be analyzed, processed, interpreted, understood, absorbed and categorized.

The university needs also the coherence among individual and collective knowledge and the exploitation needs fixed rules and routinization for an efficient management of theactivities .In brief, it is clear that the three OLM beliefs are crucial for Organizational Excellence success.

In current study, the results showed that all the three dimensions of organizational learning mechanisms variables, especially, Knowledge assimilation mechanisms, has a significantly positive relationship with the Organizational Excellence for Employees of Kafrelsheikh University. The existence of such a dynamic phenomenon influences knowledge base in Employees of University by renewing it and expanding it with the influx of new relevant knowledge. Absorptive capacity could influence the potential of employees of university to respond to new market conditions, adjustment efforts to new environment and use of information in the competitive race. It may also contribute to the creation of new opportunities for competitiveness, knowledge base strengthening and improved forecasting of future market development (Cohen \& Levinthal, 1990; Teece, Pisano \& Shuen, 1997; Van den Bosch, Volberda \& de Boer, 1999; Zahra \& George, 2002; Tu et al., 2006; Camison \& Fores, 2010). It then concluded that Knowledge assimilation mechanisms has a positive and significant relationship with strategic agility. The 
Scientific Journal for Financial and Commercial Studies and Researches

(SJFCSR) Faculty of Commerce - Damietta University

dimensions of knowledge assimilation mechanisms also predict strategic agility.

The present study found a positive association of strategic agility with Organization Excellence of for Employees of Kafrelsheikh University. With regard to the effects of strategic agility on other organizational excellence, the current results support the relationship between strategic agility and organizational excellence dimensions, which are represented in leadership excellence, services excellence, and knowledge excellence for Employees of Kafrelsheikh University. Moreover, the previous studies concluded that responsiveness, competency, flexibility and speed disclose have a positive effect on consequences significantly. In addition to the universities that wish to remain and lead in an environment characterized by transformations and intense competition, it is required that one of them possess the capabilities and agile strategies that qualify them to achieve this.

In order for universities to be able to compete efficiently in their markets, they must be distinguished by their services represented in the dimensions of strategic agility (Strategic sensitivity, collective commitment, resource liquidity) to ensure the satisfaction of their internal and external customers.

Egyptian universities have failed to achieve their goals due to the weak use of strategic flexibility and flexibility in modifying their administrative and technical procedures according to the continuous environmental variables.

The results showed that all three Organizational Learning Mechanisms dimensions are significant in model 1 and important in model 2 and that the strategic agility positively influences the organization's excellence for the Employees of Kafrelsheikh University. This, in turn, suggests that strategic agility partial mediates the relationship between Organizational learning mechanisms and organization excellence. This means that organizational learning mechanisms should have the capacity and act strategically which, in turn leads to increase in individual agility.

The collective individuals' agility consorted with organizations agility would enhance organizational excellence. Embracing the 


\section{Dr. Shahesta Elsaid Lebda}

competitive environment also requires effective tools for success as organizational learning and organizational agility (Shahrabi, 2012)، The more organizations develop and retain their Organizational learning mechanisms, the more organization will be agile and generate the highest success in the turbulent environment.

\section{Conclusion:}

In the current study, an applied study is presented the impact organizational learning mechanisms on organizational excellence for Employees of Kafrelsheikh University taking into account the strategic agility as a mediator. Overall findings proved that strategic agility partial mediates the relationship between the organizational learning mechanisms and the organizational excellence for employees of Kafrelsheikh University. Therefore, the leaders in university could use the current findings to develop specific plans and strategies for mechanism learning based on the objective basis according to the university needs of skills and expertise to develop and improve the performance levels and achieving organizational excellence. Employees in university must also own the organizational learning mechanism (Knowledge recognition, Knowledge assimilation, and Knowledge exploitation) to improve the strategic agility levels, achieve Entrepreneurship and excellence in their working field. Organizational excellence needs steps that go beyond not only following mechanism formulation and execution but also ensuring sustainability based on continuity, flexibility, and comprehensiveness of resources. It becomes a master key of excellence.

\section{References:}

- Alegre J., Chiva R., (2008) Assessing the impact of organizational learning capability on product innovation performance: An empirical test Technovation, 28 (6) , pp. 315-326.

- Armstrong M., (2000). The name has changed but has the game remained the same? In: Employee Rela- tions, 22(6): 576-593.

- Arokodare, M. A. \& Asikhia, O. U. (2020). Strategic Agility: Achieving Superior Organizational Performance through Strategic 
Scientific Journal for Financial and Commercial Studies and Researches (SJFCSR) Faculty of Commerce - Damietta University

Global Journal of Management and Business Research: An Administration and Management. Volume 20 Issue 3 Version 1.0.

- Atallah, R. R., \& Naser, S. S. A. (2014). Data Mining Techniques in Higher Education an Empirical Study for the University of Palestine. IJMER, 4(4), 48-52.

- Berghman , Liselore , (2013). Deliberate Learning Mechanisms for Stimulating Strategic Innovation Capacity, Journal: Long Range Planning, vol. 46, no. 1-2, p. 39-71.

- Camisón, C., \& Forés, B. (2010). Knowledge absorptive capacity: New insights for its conceptualization and measurement. Journal of Business Research, 63(7), 707-715.

- Chiva R., Ghauri, P., \& Alegre, J., (2014). Organizational learning, innovation, internationalization: a complex system model. British Journal of management $\mathrm{m}$ 25, 687-705.

- Cohen and Levinthal, (1990), W.M. Cohen, D.A. Levinthal Absorptive capacity: a new perspective on learning and innovation, Adm. Sci. Q., 35 (1) (1990), pp. 128-152

- Cohen, W. M. and Levin, R. C. (1989). 'Empirical studies of innovation and market structure.' In (R. C. Schmalensee and R. Willig, Eds.) Handbook of Industrial Organization Vo1. II. Amsterdam: Elsevier Science Publishers, B.V

- Camisón, C., \& Forés, B. (2010). Knowledge absorptive capacity: New insights for its conceptualization and measurement. Journal of Business Research, 63(7), 707-715.

- Dill, D. (1999), 'Academic accountability and university adaptation: The architecture of an academic learning organization', Higher Education, 38, 127-139.

- Dixon, N.M. (1994). The organizational learning cycle: How we can learn collectively. New York:McGraw-Hill.

- Doz, Y., Kosonen, M., (2008). "Fast Strategy: How Strategic Agility will help you stay ahead of the game", Wharton School Press. 


\section{Dr. Shahesta Elsaid Lebda}

- Fiol, C.M., \& Lyles, M.A. (1985), Organizational learning. academy of management review, 10(4), 803-813.

- García-Morales, V.J., Jiménez-Barrionuevo, M.M. and GutiérrezGutiérrez, L. (2012) 'Transformational leadership influence on organizational performance through organizationallearning and innovation', Journal of Business Research, Vol. 65, No. 7, pp.1040 1050 .

- Gebauer, H., (2011). Exploring the contribution of management innovation to the evolution of dynamic capabilities. Industrial Marketing Management 40, 1238-1250.

- Ghoshal, S. (1987) Global strategy: An organizing framework. Strategic Management Journal, 5, 425-40.

- Grant, R. (2000). Contemporary Strategy Analysis. UK: Oxford.

- Grote, D., (2002). The Performance Appraisal Question and Answer Book Survival Guide for Managers. United States of America.

- Hair,J. F., Black, W. C., Babin, B. J., Anderson, R. E., \& Tatham, R. L. (2006). Multivariate data analysis (6th ed.). Pearson Education International, New Jersey.

- Hoffman, J.J., Hoelscher and K. Sherif, 2005. Social capital, Knowledge management and sustained superior performance. J. Knowledge Manage., 9: 93-100.

- Hsu, Y.-H., \& Fang, W. (2009). Intellectual capital and new product development performance: The mediating role of organizational learning capability. Technological Forecasting \& Social Change, 76(5), 664-677. Doi: innovation', Strategic Management Journal, Vol. $31, \quad$ No. $\quad 5, \quad$ pp.547-561. http://dx.doi.org/10.1016/j.techfore.2008.03.012.

- Jerez-Gomez, P., Cespedes-Lorente, J. and Valle-Cabrera, R. (2005), "Organizational learning capability: a proposal of measurement", Journal of Business Research, Vol. 58 No. 6, pp. 715-25. 
Scientific Journal for Financial and Commercial Studies and Researches

(SJFCSR) Faculty of Commerce - Damietta University

- Jiménez-Jiménez D., Cearra-Navarro J.G., (2007). The performance effect of organizational learning and market orientation Industrial Marketing Management, 36 (6), pp. 694-708.

- Johnson, C. G., \& Bailey, M. R. (2010). Validating an organizational action system model from a learning and performing perspective. In Academy of Management Proceedings (Vol. 20, No. 9, pp. 1-34).

- Lee, S., Courtney, J.F. \& O'Keefe, R.M., (1992). A system for organizational learning using cognitive maps. OMEGA International Journal of Management Science, 20(1), 23-36.

- Liao, J., Welsch, H., \& Stoica, M. (2003). Organizational absorptive capacity and responsiveness: An empirical investigation of growthoriented SMEs Entrepreneurship: Theory \& Practice, 28(1), 63-85.

- Lipshitz, R., Popper, M. \& Friedman, V.A., (2002). Multi-facet model of organizational learning. Journal of Applied Behavioral Science, 38, 78-98.

- Mellahi, kamel \& Miner ,Anne (2020), Strategic agility through improvisational capabilities: Implications for a paradox-sensitive HRM , Human Resource Management Review , Volume 30, Issue 1, March 2020, 100695

- Nemeth L. " Measuring organizational learning dissertation, university of western Ontario, London.

- Nonaka, I. \& Takeuchi, H., (1995) The knowledge creating company: How Japanese companies foster creativity and innovation for competitive advantage. New York: Oxford University Press. Published, (2002). Business Academy of Management Review.

- Raftery D., (2006). in Pursuit of Teaching Excellence: Encouraging Teaching Excellence in Higher Education. In: Proceedings of the AISHE Conference, Maynooth August.

- Reed, J. \& Vakola, M. (2006), "What role can a training needs analysis play in organizational change?", Journal of Organizational Change Management, Vol. 19 No. 3, pp. 393-407. 


\section{Dr. Shahesta Elsaid Lebda}

- Ruthwell WJ, Markward MJ. (1995). Learning in practice. Construction Manager Journal, 9, 1-4.

- Santala, Maarit, thesis, Master's, (2009)." Strategic Agility in a Small Knowledge Intensive Business Services Company": Case Swot Consulting, Department of Marketing and Management, Helsingln, Kauppakorkeakoulu Helsinki school, of economics, p36.

- Santos-Vijande, M.L., López-Sánchez, J.Á. and Trespalacios, J.A. (2012) 'How organizational learning affects a firm's flexibility, competitive strategy, and performance', Journal of Business Research, Vol. 65, No. 8, pp.1079-1089.

- Schwandt, D.R. (1995). Learning as an Organization: A Journey into Chaos. In S. Chawla and J. Renesch (Eds.), Learning Organizations: Developing Cultures for Tomorrow's Workplace, 365-379. Portland, OR: Productivity Press.

- Sekaran, U., \& Bougie, R. (2016). Research methods for business: A skill-building approach (7th ed.). Wiley, New York.

- Sekaran, Uma, \& Bougie, Roger (2013). Research methods for business: A skill-building approach (6th ed.). Wiley, New York.

- Sessa, V. I., London, M., Pingor, C., Gullu, B., \& Patel, J. (2011). Adaptive, generative, and transformative learning in project teams. Team Performance Management: An International Journal, 17(3/4), 146-167.

- Shahrabi, B. (2012). The Role of organizational learning and agility in change management in state enterprises: a customer-oriented approach. International Research Journal of Applied and Basic Sciences, 3(12), 2540-2547.

- Swart, W. and Duncan, S. (2005), "A methodology for assuring the quality human performance", International Journal of Computer Integrated Manufacturing, Vol. 18 No. 6, pp. 487-97.

- Teece, D. J., Pisano, G., \& Shuen, A. (1997). Dynamic Capabilities and Strategic Management. Strategic Management Journal, 18(7), 509-533. DOI: 10.1002/(SICI)1097- 0266(199708)18:73.0.CO;2-Z. 
Scientific Journal for Financial and Commercial Studies and Researches (SJFCSR) Faculty of Commerce - Damietta University

- Thompson, Steven K., (2012). Sampling, Third Edition, P: 59 - 60.

- Tu, Z., Wang, L., Arbeitman, M. N., Chen, T., \& Sun, F. (2006). An integrative approach for causal gene identification and gene regulatory pathway inference. Bioinformatics, 22(14), e489-e496.

- Van den Bosch, F. A., Volberda, H. W., \& De Boer, M. (1999). Coevolution of firm absorptive capacity and knowledge environment: Organizational forms and combinative capabilities. Organization science, 10(5), 551-568.

- Yasin, N. M., Ramayah, T., Mohamad, O., \& Wah, L. L. (2009). The mediating effects of attitude towards parallel imports in consumer personality-Purchase intention linkage. Jurnal Pengurusan (UKM Journal of Management), 28.

- Zahra, S. A., \& George, G. (2002). Absorptive capacity: A review, reconceptualization, and extension. Academy of management review, 27(2), 185-203.

- Zahra, S. A., \& George, G. (2002). Absorptive capacity: A review, reconceptualization and extension. Academy of Management Review, 27(2), 185-203.

- Zhou, K. Z., \& Wu, F. (2010). Technological capability, strategic flexibility, and product innovation. Strategic Management Journal, $31(5), 547-561$. 


\title{
Dr. Shahesta Elsaid Lebda
}

\section{الرشاقتا الاستراتيجيتّ كمتغغير وسيط بين اليات التعلم التنظيمي والتميز

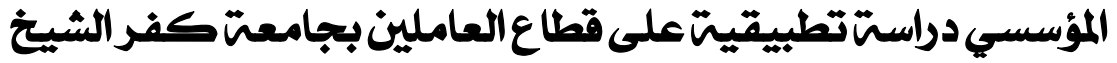

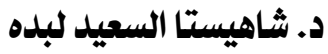 \\ مدرس بقسم ادارة الأعمال \\ كلية التجارة - جامعة كفر الشيخ \\ shahylebda@gmail.com
}

الملخص:

تهدف هذه الدر اسة الى معرفة العلاقة بين اليات التعلم التنظيمي والرشاقة الاستر اتيجية

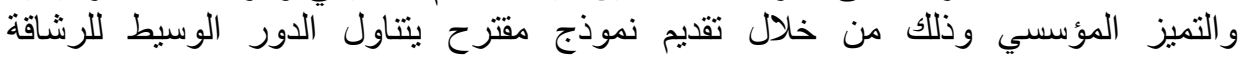

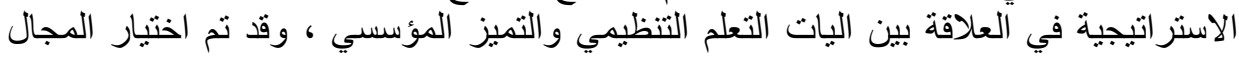

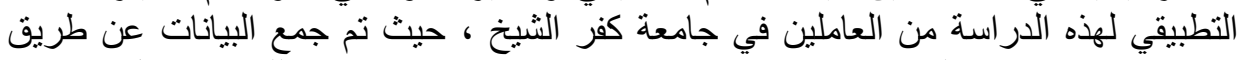

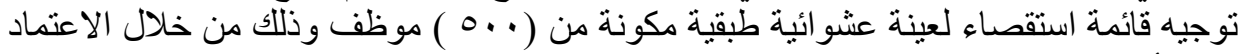

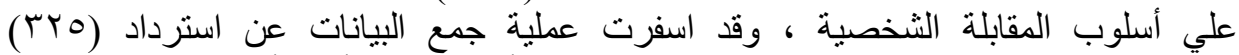

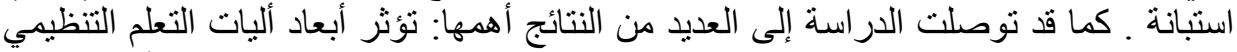

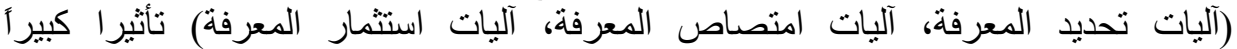

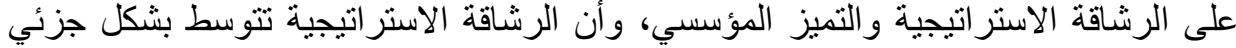

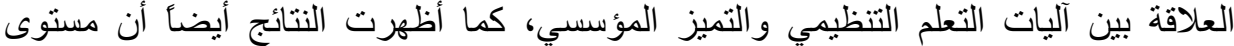

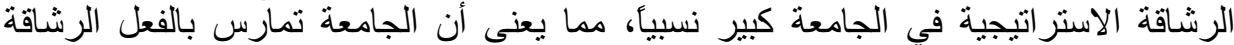

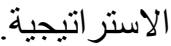

الكلمات المفتاحيت: اليات التعلم التنظيمي، الرشاقة الاستراتيجية، التميز المؤسسي 